to ideas differing from those involved in the "new theory," which, so far as extracts such as the above go, appears to include nothing whatever of a theoretical nature.

Even in Prof. Ostwald's letter there are, however, indications that in his book he went beyond the mere statement of the laws of solutions. For example, he says : "In my book the question is this one of facts, and although I have therein made more use of molecular considerations than I should at present hold to be proper, yet I have done so only to render more clear the actual relations, and never to prove quantitative laws."

Now it was solely the "develonment of the consequences of facts "-this use, which Prof. Ostwald admits to have been exces sive, of "molecular considerations" - which has generally been, and was by me, styled the " physical theory." The facts themselves no one can question; indeed, I took pains to point out in my review that the facts, as given in the book, would alone serve to make it valuable. The theoretical matter, however, called for separate consideration. It alone was, and, so far as I can see, it alone could be, designated the " physical theory."

In denying the contrast between the so-called chemical and physical theories, Prof. Ostwald declares that he never maintained "that no interaction takes place between the solvent and the dissolved substance." If such was his opinion when writing his book, it may be asked, Why in all fairness should he have defined solutions as homogeneous mixtures? Why did he not state clearly that interactions between solvent and dissolved substance were possible? It is quite true that, in my review, instances were given of chemical expressions used in the book, but no stress was put upon these by the author as indicating the general occurrence of chemical changes in solutions. They seemed to arise, not because of, but rather in spite of, the author's idea of the nature of solution, and could only be regarded as inconsistencies. The theme of the book was the explanation of the properties even of concentrated solutions by considering the interactions of molecules of the same kind, by treating the dissolved substance as if it were gasified. If such a method of treatment were described as "physical," I think the commonly accepted meaning of the word was in no way impaired.

Indeed, much of F'rof. Ostwald's book can hardly be justified if interactions of a chemical nature are probable in solutions. For instance, several pages are devoted to the use of van der Waals's equation in dealing with solutions. To anyone familiar with the deduction of this equation, the validity of its application to a solution even when the solvent is regarded as indifferent is highly questionable. If, however, it is admitted that something of the nature of a chemical reaction may occur between solvent and dissolved substance, that the latter may not be in a pseudo-gaseous condition, then the application of the equation can hardly be termed otherwise than meaningless.

In conclusion, I can only express regret if my review has tended to create further misconception on this vexed question of solution. At the same time, I hope I have been able to indicate to Prof. Ostwaid the points which led to my use of the terms to which he objects; and I venture to think that in the discrepancies which appear to exist between the ideas as given in his letter, and those which the reader has to gather from his book, is to be found sufficient reason for the use of the statements to which exception has been taken.

J. W. RODGER.

London, February 1.

\section{Arrow Poison.}

IN I889 a French naval surgeon, M. Ledantec, published in the Annales de l'Institut Pasteur the result of some investigations he had made into the nature of the arrow poison of the natives of the New Hebrides. Wounds from these arrows give rise, as is well known, to tetanus, and $M$. Ledantec was able, by the subcutaneous irijection of the scraped off poison, to kill guinea-pigs under typical tetanic symptoms. He learnt from a Kanaka that they are prepared by smearing the arrow-heads (which are made of human bone) first with tree gum and then with mud from a swamp, which mud he found to contain numbers of Nicolaier's tetanus bacillus.

As far as I am aware, this has been recorded only of the natives of the New Hebrides and some of the neighbouring groups (the arrow poison of Stanley's dwarfs is certainly not the same), and I was therefore much interested some days ago by coming accidentally upon an old record which seems to show that the natives of the Cape Verd coast were accustomed, more than three hundred years ago, to get rid of their enemies in a similar manner. In Hakluyt's "Voyager's Tales," published in 1589 ( $\mathrm{I}$ refer to the little reprint edited in I 889 by Henry Morley), is the narrative of one Miles Phillips, in which occurs the following passage :- "Upon the 18 th day of the same month (November 1567) we came to an anchor upon the coast of Africa at Cape Verde, in twelve fathoms of water, and here our General landed certain of our men, to the number of 160 or thereabouts, seeking to take some negroes. And they, going up into the country for the space of six miles, were encountered with a great number of negroes, who with their envenomed arrows did hurt a great number of our men, so that they were enforced to retire to the ships, in which contest they recovered but a few negroes; and of these our men which were hurt with their envenomed arrows, there died to the number of seven or eight in a very strange manner, with their mouths shut, so that we were forced to put sticks and other things into their mouths to keep them open." In the language of modern medicine, they succumbed to tetanus traumaticus. The voyagers left the coast soon after, and there is no further mention of the natives or of the wounded.

There is, of course, no proof that the arrows were poisoned with mud or earth, but the probability is considerable. The chief interest lies in the age of the record, which forms in some manner a pendent to the researches of M. Bossano (Comptes rendus, 1888), which showed the tetanus bacillus to have a very wide distribution in space.

It is a curious consideration that this and the other famous arrow poison, curare, both kill by their action on the voluntary muscles, the action of one being diametrically opposed to that of the other.

Davos Platz, Switzerland, January 30.

A. COPPEN JONES.

\section{The Implications of Science.}

Hitherto prevented from again writing, I cannot now remain passive and allow Mr. Dixon to escape from bis irrational position under cover of a cloud of verbiage-like a cuttle-fish through water made turbid by its ink.

In my lecture I pointed out that certain truths are implied in all physical science. They are so implied. If Mr. Dixon thinks they are not, it is for him to show how experimental science could be carried on, with any real, serious doubt about them. This he has certainly not yet done.

Our knowledge of our own existence "in the present," is knowledge of a particular concrete fact, not of an abstract necessary truth. That "whatever feels, simultaneously exists," is such a "necessary truth," but it is an abuse of language to apply that term to anything which may cease to exist the moment after its existence is recognized.

That "nothing can simultaneously be existent and nonexistent," does not at all depend upon "terms" or "definitions," but is a law of "things." It would not lose its validity and objective truth, not only if there were no such things as "terms" and "definitions"; it would not lose it if the whole human race came to an end.

I am glad to find ny critic does " not doubt" that if he lost an eye his condition would thereby be modified, but if he does not also see that this applies and must apply everywhere and everywhen, I do not envy him his power of mental vision.

Oriental Club, February 2.

St. George Mivart.

\section{The New Forest in Danger.}

IN connection with my letter which appeared in NATURE of the 28th ult. (p. 29.5), it may interest some of your readers to know that the petitions, to which I referred, in support of the Bill for excepting the New Forest from the operation of the Ranges Act, I 891 , have already been signed by Lord Walsingham, F.R.S. Prof. C. Stewart (President of the Linnean Society), Sir Joseph D. Hooker, F.R.S., Dr. P. L. Sclater, F.R.S., Mr. Osbert Salvin, F.R.S., Dr. A. Günther, F.R.S., Dr. H. Woodward, F.R.S., Mr. W. Carruthers, F.R.S., Dr. D. Sharp, F.R.S., Mr. Thiselton-Dyer, C.M.G., F.R.S., Mr. H. W. Bates, F.R.S., Mr. F. DuCane-Godman, F.R.S., Dr. G. Buchanan, F.R.S., Dr. B. Richardson, F.R.S., Prof. J. O. Westwcod (Professor of Zoology, Oxford), Dr. Thorne-Thorne, F.R.S., Mr. J. G. Baker, F.R.S., Mr. W. H. Preece, F.R.S., Mr. Botting Hemsley, F.R.S., Mr. E. B. Poulton, F.R.S., Mr. R. McLachlan, F.R.S., Mr. C. B. Clarke, F.R.S., Major-General Carden, Prof. Jeffrey Bell (Secretary of the Microscopical

NO. I I63, vOL. 45$]$ 